\title{
Strategic Planning in Academic Libraries
}

\author{
Sheila Corrall \\ University of Southampton, Southampton, United Kingdom
}

\section{INTRODUCTION}

Strategic planning is essentially about deciding and refining organizational objectives and working consistently and persistently to translate those objectives into actions and outcomes. It requires insight and foresight to interpret past events and present trends to determine future directions. Strategic planners need to have eclectic interests, a flexible mindset, and an inclusive style that involves people in envisaging change, developing strategies, and making plans. Planning is often a formal requirement, but in any case it is good management practice and has several potential benefits, particularly when carried out in a participative style with stakeholder involvement. For example:

- It brings new perspectives and insights to service development by posing unusual questions and forcing consideration of options.

- It strengthens the case for funding and provides the necessary context for both the annual budget round and special funding bids.

- It enables delegated decisions and quick flexible responses on the front line, improving satisfaction for customers and staff.

- It inspires confidence in the service by demonstrating an understanding of the key issues and showing how they will be addressed.

- It creates a shared view of the future and commitment to doing new things, facilitating change by giving people a sense of ownership.

Strategic planning has various functions: to clarify organizational purpose and objectives; to establish corporate directions and priorities; to assess environmental drivers and constraints; to identify critical issues and pressures; to determine resource allocation and utilization; to improve internal coherence and coordination; and to inform operational decisions and actions.

This article covers the core concepts of strategic planning, the historical context of its development in academic libraries, and contemporary approaches to library strategy. It reviews published literature and current practice, concentrating on planning processes, strategy documents and key elements of strategic planning.

\section{CORE CONCEPTS}

Effective strategic planning involves understanding the business arena, assessing your resource base and creating a shared view of the future, by asking fundamental questions such as:

- Why do we exist? What business are we in? (mission)

- Where are we now? How did we get here? (situation audit)

- What factors will impact our future? (environmental appraisal) 
- What do we want to be? Where do we want to go? (vision and goals)

- How can we get there? What are the implications? (strategic options)

- What needs to be done? Who will do it? When? (action plans)

- How will we track progress? (performance indicators)

The terminology of strategy and planning is confusing. There is no standard usage; the same terms are used in different ways, and they can have different meanings according to context. People often confuse "policy" and "strategy" and find it difficult to differentiate "mission" and "vision." Commentators often conceptualize aims, directions, goals, objectives, strategies, and targets as a hierarchy of objectives (using "objective" as a generic term) but may place these terms in different orders; the choice of term at successive levels in the hierarchy is not significant, but it is important to have consistency of usage within an organization to aid communication and avoid confusion.

The word "strategy" is used at one level to denote overall direction, as indicated by Johnson and Scholes, "Strategy is the direction and scope of an organization over the long term: which achieves advantage for the organization through its configuration of resources within a changing environment, to meet the needs of markets and to fulfil stakeholder expectations." [1]

However, as well as representing the overall objective for an organization or what it aims to do, "strategy" is also used to describe how an organization will achieve its objective or aim. At this level, strategies are defined sets or emerging patterns of actions and tasks taking the organization toward its goals and targets. Drucker accordingly describes "strategy" as "a company's basic approach to achieving its overall objectives" and defines "strategic planning" as: "the planning for a company's long-term future that includes the setting of major overall objectives, the determination of the basic approaches to be used in pursuing these objectives, and the means to be used in obtaining the necessary resources to be employed." ${ }^{[2]}$

Despite differences in terminology and presentation, literature and practice point to general consensus about what constitutes strategic planning or "strategic management" (the term often preferred now to emphasize the iterative nature and comprehensive scope of the strategy process). There are four main aspects, that can be seen as a set of interlocking components: environmental appraisal, strategic profiling, strategy development, and program management.

\section{Environmental Appraisal}

This aspect covers researching and analyzing the forces of the external world, including your own industry/sector and its marketplace, as well as reviewing and auditing the internal situation, especially your performance and resources. The tools used include environmental scanning, PEST/STEP analysis, stakeholder mapping, competitive benchmarking, SWOT, and crossimpact analysis. The typical output is a set of formal planning assumptions to inform other aspects of the planning process.

\section{Strategic Profiling}

This involves discussing and agreeing fundamental issues, such as the scope, purpose, and functions of your organization; its guiding principles and philosophies; your desired future situation and the direction required to get there. Tools used include: mission, positioning, vision, and values statements; key result areas; critical success factors; goals; and targets. The typical 
output is a series of related objectives statements to inform the development and evaluation of strategies.

\section{Strategy Development}

This requires the formation and adoption of strategies, action programs, and resource plans, by identifying and evaluating options and sensitivities, considering supporting strategies and contingency plans, and specifying performance indicators. Tools used include generic strategy models, portfolio matrices, and cost-benefit analysis. The typical output is a formal strategy document or plan to inform operational/project planning and funding bids.

\section{Program Management}

This aspect includes taking actions and monitoring progress, reviewing objectives and refining plans, elaborating tasks and incorporating targets into annual budgets and operational plans. Tools used include gantt charts, milestone plans, responsibility charts, risk analysis, and performance measurement. Typical outputs are project plans, operational plans, budget projections, risk registers, progress reports, financial reports, and other monitoring statements.

There is considerable overlap between corporate/business strategy and marketing strategy, and many of the models and tools used in strategic planning are concerned with marketing variables. However, strategic planning is essentially about defining the business (or businesses) of the organization and setting overall business objectives, whereas marketing plans elaborate strategies to achieve these objectives; market research is an essential aspect of the environmental analysis that underpins strategic planning.

\section{HISTORICAL CONTEXT}

Strategic planning originated in the United States during the 1960s and spread to Europe and beyond in the 1970s and 1980s, becoming an accepted part of managerial thinking and practice in the business world and the public sector. It is distinguished from other types of planning by its focus on environmental trends and concern with fundamental questions about where an organization is going and how it will get there. Although long-range planning is associated with incremental growth and evolutionary change, strategic planning is particularly associated with revolutionary change or even total reconception.

The adoption of strategic planning concepts and techniques by library and information service managers has followed the general trend, with American libraries acting as pioneers from the 1970s onward, and libraries in other countries gradually following their lead. In the United States, many university libraries engaged in planning as part of an institutionwide activity, but in the United Kingdom, they often became involved in strategic planning ahead of their parent bodies.

The Association of Research Libraries (ARL) has played a significant part in the development of strategic planning in academic libraries through its Office of Management Studies, which carries out consultancy and training for its members ${ }^{[3-5]}$ and has published several collections of library planning documents. ${ }^{[6-8]}$ In the United Kingdom, the Society of College, National and University Libraries (SCONUL) has worked with the Universities and Colleges Information Systems Association and the Higher Education Staff Development Agency 
to develop strategic management capability in the sector, by offering a strategic management program for service directors and including strategic planning and scenario development in a course for service managers. ${ }^{[9]}$

Funding pressures in the higher education sector over the last two decades have made strategic planning a managerial necessity, and many institutions now have elaborate and sophisticated systems to meet internal needs and external requirements. In the United Kingdom, funding bodies have formally required institutions to submit both general (corporate) plans and more specific strategies as a condition for the release of funds. Library planning, therefore, needs to be linked to and integrated with an array of institutional, functional, and departmental strategies and plans, in a complex system, which is best seen as a network or web of strategies, rather than the traditional conception as a hierarchy of plans. This issue was highlighted by the Ellard report on performance indicators for academic libraries in 1995, which included "the cohesiveness between the mission, aims and objectives and strategic plan of the institution and those of its library" as an indicator of integration. ${ }^{[10]}$

\section{PUBLISHED LITERATURE}

There are numerous publications on business planning and corporate strategy but relatively few titles on strategic planning for academic institutions and their libraries. Most of the literature on strategic management in higher education is based on practical case studies, with some authors offering a more objective or theoretical perspective. Academic library strategists have accordingly drawn on models outside higher education as well as learning from professional colleagues.

\section{Academic Strategy}

Among the many strategy writers cited, Chandler, ${ }^{[11]}$ Bryson, ${ }^{[12]}$ and Steiner ${ }^{[13]}$ have been particularly influential, in addition to marketing guru Kotler ${ }^{[14]}$ and the higher education specialists, Cope ${ }^{[15]}$ and Keller. ${ }^{[16]}$ Although American writers have led the field, contributors from other countries have emerged more recently with Meade's account of strategic reorientation at the University of Otago ${ }^{[17]}$ and Watson's reflections on strategic management in contemporary England, which draw on the remodeling of the corporate and strategic plans of the University of Brighton. ${ }^{[18]}$

The central place of strategic planning in higher education is further evidenced by more specific and practical publications issued in the last few years. Berge and Schrum describe how the development and implementation of technology-enhanced distance learning programs need to be integrated into institutional strategic planning (and budgeting). ${ }^{[19]}$ At a more general level, Lerner's "strategic planning primer for higher education" takes readers through the key steps and alerts them to potential pitfalls. She also explains the distinctive features of university planning and highlights business models that have proved useful in the sector, providing links to the California State University Northridge strategic planning site. ${ }^{[20]}$ In England, the Higher Education Funding Council has issued a 44-page guide for heads of institutions, senior managers and governing bodies, based on consultation and case studies across the sector. ${ }^{[21]}$ 


\section{Library Planning}

Textbooks on library planning began to appear in the 1980s. The pioneering 1984 volume by Riggs, Strategic Planning for Library Managers, looks somewhat dated now, but it made a significant contribution in introducing business concepts and techniques to the library community. ${ }^{[22]}$ McKee's 1989 book, Planning Library Service, ranged more broadly across the whole field of management and was the first British treatment of the topic. ${ }^{[23]}$ More practical guidance on strategic planning was provided in Jacob's How-To-Do-It Manual ${ }^{[24]}$ and Corrall's Know How Guide. ${ }^{[25]}$ The latter was subsequently revised and expanded into a much more comprehensive handbook, Strategic Management of Information Services, which includes many examples from the literature and practice of academic librarianship. ${ }^{[26]}$ Other books have concentrated on particular aspects of or approaches to library strategy: Giesecke introduces the theory and practice of scenario planning; ${ }^{[27]}$ Weingand explains how futuring methods can be used with conventional marketing/planning techniques; ${ }^{[28]}$ and Gorman discusses the core values of libraries and librarianship. ${ }^{[29]}$

Articles on academic library planning can be traced back to the same era. Although the concept of strategic planning is not mentioned and the term "strategies" is only used in passing, McClure's 1978 contribution to College \& Research Libraries is in practice an early discussion of the benefits of a formal approach to strategy with practical suggestions about how to do it. ${ }^{\text {[30] }}$ Davis (writing from the perspective of a sympathetic bystander) similarly advocates a proactive approach to planning, with staff participation and stakeholder involvement. ${ }^{[31]}$

\section{Case studies}

With the exception of the monographs by Biddle ${ }^{[32]}$ and Hayes, ${ }^{[33]}$ much of the literature on academic library planning consists of journal articles describing and evaluating the planning processes used at particular institutions. Thus, Ensor details the data-gathering methods used at Indiana State University, ${ }^{[34]}$ Baker describes the top-down process adopted at Massachusetts Institute of Technology, ${ }^{[35]}$ Brindley outlines the more participative style used at Aston University, ${ }^{[36]}$ Gratch and Wood discuss the approach taken to implementation at Bowling Green State University, ${ }^{[37]}$ Butler and Davis reflect on their respective experiences at Michigan State University and the State University of New York at Albany, ${ }^{[38]}$ Lee identifies factors determining success at Harvard College, ${ }^{[39]}$ Blunden-Ellis elaborates the key issues addressed in planning the Consortium of Academic Libraries in Manchester, ${ }^{[40]}$ and Shoaf describes the proactive and highly participative approach used at Brown University. ${ }^{[41]}$

In contrast to these relatively brief accounts, Lynch provides an in-depth case study with extensive insights into the planning issues facing the University of Illinois at Chicago Library. This volume contains eight chapters from colleagues involved in the planning process, reflecting their different views on the library and its environment. The book also reproduces the strategic plan eventually developed by the library. ${ }^{[42]}$ Another distinctive collection is the volume edited by Williams containing 14 articles offering multiple perspectives on the planning processes at 12 U.S. institutions. The authors include college and university presidents, provosts, and planners as well as librarians. ${ }^{[43]}$ Among these is an early appraisal of how strategic planning can facilitate the convergence of a library with cognate services: Watson argues that the cooperation required to develop a unitwide plan helped managers "gain a broader perspective of the roles of each of the components and envision new ways in which the components might interact in support of 
each other." [44]

\section{Specific aspects}

Other authors focus on specific dimensions of strategic planning. Wilson ${ }^{[45]}$ and Brophy ${ }^{[46]}$ both discuss the mission of the academic library; Forsman suggests how organizational values can be used in planning; ${ }^{[47]}$ Birdsall and Hersley present a planning model emphasizing stakeholder involvement; ${ }^{[48]}$ Michalak considers the strategic planning of library facilities; ${ }^{49]}$ Hewison describes a participative approach to vision statements; ${ }^{[50]}$ Tuck considers the use of surveys and evaluation in implementing and monitoring a strategic plan; ${ }^{[51]}$ Bevan and Dolphin describe the incorporation of an IT strategy into a library plan; ${ }^{\left[{ }^{22]}\right.}$ Birdsall revisits stakeholder engagement and explores the political dimensions of strategic planning; ${ }^{[53]}$ Corrall and Brewerton report on the use of scenarios in strategic visioning and space planning; ${ }^{[54]},{ }^{[55]}$ and Feinman shows how library staff can contribute to and influence university strategic planning. ${ }^{[56]}$

\section{PLANNING PROCESSES}

Both planning horizons (time spans covered by plans) and planning time lines (time devoted to the process) have shortened significantly in recent years. In past decades, long-range plans covered 5, 10, or even 20 years, but today organizations generally opt for no more than 5 yearsoften only 3 - and the same pattern is evident in academic libraries. Irrespective of the period covered, strategic plans are usually reviewed annually to inform yearly budgets and operational plans and sometimes "rolled forward" by dropping the first year and adding another at the end. (This practice of edging forward incrementally is quite different from the sort of fundamental review that strategic planning requires and, therefore, should only be seen as an interim exercise limited to no more than two or three iterations.)

In the 1980s, it was quite common for first iterations of strategic planning to be conducted over a period of 12 months or longer, with some reported instances of exercises taking 18 months to 2 years - notably, the University of Illinois at Chicago. ${ }^{[42]}$ Today, the period of any formally defined process is more likely to be 6 months or less, because the pace of change is so fast that a longer gestation period makes little sense. This compression of the formal strategic planning process into a matter of months makes the requirement for library managers to engage staff continuously in less formal strategic thinking and environmental scanning even more important.

One of the trends evident in both library planning and business strategy processes is the move to a more participative and inclusive style, with more extensive involvement of staff, customers, and other stakeholders. Another tendency is for managers to acknowledge "real-time strategy" as a continuous (learning) process instead of seeing it as a "one-off" exercise or part of an annual ritual. The formal or organized planning process has thus become more concerned with capturing information and decisions rather than initiating environmental scans, competitive benchmarking, customer surveys, etc. because the latter are now ongoing activities in many academic libraries.

Strategic planning has been conceptualized as a series of fundamental questions and a set of interlocking components. It can also be seen in more practical terms as a sequence of iterative steps. Models for operationalizing the strategic planning process vary and need to be considered in relation to the size and type of organization and the scope and purpose of the plan. Library 
managers have learned over the years that planning processes (whatever their scale) need to be properly managed and carefully planned. The key tasks involved can be summarized as follows:

- Defining the project.

- Auditing the situation.

- Setting strategic objectives.

- Identifying different strategies.

- Evaluating the alternatives.

- Preparing budget estimates.

- Formulating the plan.

- Initiating action programs.

- Monitoring strategy progress.

- Reviewing the plan.

These tasks can be interpreted at various levels. For example, "setting strategic objectives" could include a full review of organizational values, purpose, and functions, and the development of a strategic vision, or it might be confined to determining or just confirming strategic directions and goals for the next year or two. Apart from the crucial first step of defining the task ("planning to plan"), the ordering of tasks is largely a matter of personal (or organizational) choice, so that some people like to start with strategic objectives (including mission and vision), whereas others prefer to begin with situation analysis. The last three tasks move beyond planning to implementation, but often information obtained and insights gained here will prompt revision and rethinking of earlier work, demonstrating that the process needs to be seen as iterative and interactive, rather than linear.

\section{Practical Examples}

Academic libraries use a variety of planning models and methods, but some common themes are evident from their websites and documents, such as the use of steering committees, management retreats, facilitated workshops, and focus groups. New Mexico State University Library designed a planning process around five special committees, ${ }^{[57]}$ whereas the University of Memphis Libraries worked through a Strategic Plan Team and five Goal Teams, with Objective Teams to oversee implementation. ${ }^{[58]}$

The University of Queensland Library sees strategic planning as a dynamic activity involving all staff and has used an "appreciative inquiry process" (discover, dream, design, deliver) since 1998. ${ }^{[59]}$ Curtin Library and Information Service followed the University's strategic planning framework, based on Kaplan and Norton's Balanced Scorecard, ${ }^{[60]}{ }^{[61]}$ and the University of Arizona Library works through a team structure using tools and techniques based on the Japanese concept of Hoshin planning to focus on "a few breakthrough goals that are vital to the Library's success." [62]

Textbooks and case studies point to the pitfalls of planning exercises. Common mistakes include: allowing some managers to opt out; assigning responsibilities to committees rather than individuals; confusing strategic planning with operational planning; constructing overelaborate systems and procedures; generating long lists of unprioritized initiatives; ignoring resource implications and funding issues; and not following through from strategy to action. 


\section{STRATEGY DOCUMENTS}

Many critics argue that it is not worth bothering with formal plans because they become out-ofdate almost as soon as they are written. This view assumes that strategy documents are static entities, but a sensible process makes provision for refining and updating both the plans of an organization and the assumptions on which they are based. Mount Holyoke College Library, Information, and Technology Services explicitly describe their plan as "a continually evolving document whose evolution is very dependent upon feedback from the community." [63] Many academic libraries are actually required to submit some form of plan as part of an institutional planning and budgeting cycle, but in any case there are sound reasons for documenting plans in print or electronically.

1. The process of writing and editing a strategy documents forces people to think through their goals and objectives and serves as a double check on overall consistency, organizational capacity, and other critical issues.

2. Written plans provide a visual medium of communication for both internal and external audiences and make it easier to convey a consistent message to staff and others in different places at different times.

3. A formal record of intended activities provides a vital mechanism for control, enabling regular and ad hoc monitoring of whether specified actions have been carried out and underlying assumptions have proved correct.

The level of detail included in a plan will be influenced by formal requirements, personal preferences, and specific decisions on whether to develop a hierarchy or family of plans presenting successively more detailed elaborations of strategies, actions, and timetables. The plan needs to state what you intend to do and why, how you will do it and when, with enough information on background and resources to convince readers. It is essential to define the scope of the plan, particularly the period covered and the services included (e.g., library services only or library, IT, and educational media provision). It is desirable to provide a contents list and an executive summary if the document runs to more than five pages.

Contemporary academic library planning statements vary significantly in length, format, and contents. The trend is toward more concise documents, covering shorter time spans, with a sharper focus on intended results. Lengthy descriptions of service characteristics have generally been replaced with brief summaries of strategic issues, proposed approaches, and performance indicators. Vision statements have become more prominent, often forming the main narrative section of the plan and sometimes comprising a set of alternative scenarios representing different planning assumptions. Many elements previously included (such as SWOT analyses and statistical data) are now relegated to appendices or excluded altogether.

\section{Practical Examples}

Most plans today cover 5-10 pages, although there are a few examples of much longer documents - notably, the plans of Monash, Rutgers, and Syracuse universities, which all contain around $25-30$ pages. ${ }^{[64-66]}$ The first library plans produced in the 1980 s ranged from basic typescripts for internal use only to glossy publications made available to all. Many libraries now publish their plans via their websites, often offering several formats (typically, HTML and PDF 
or Word).

The style of presentation is generally quite simple, but some libraries have been more creative in their use of layout and design: Macquarie University Library makes use of blocks and columns of text in double-page spreads to convey "where we want to be," "desired outcomes," and "how we will do it" in relation to teaching partnerships, research partnerships, and community outreach. ${ }^{[67]}$ Other university libraries have given their plans meaningful titles to reinforce the key messages of their documents (e.g., Rutgers: "A bridge to the future;", [65] Syracuse: "Targets for transformation;" ${ }^{[66]}$ and the University of Sheffield: "New worlds of information." [68]

More significantly, there is a trend toward using websites to make the planning process more transparent and participative. The strategic planning home page of the University of Arizona Library provides links to extensive documentation, such as the "team charge" and other descriptions of the planning process, in addition to end products from that process (including a 17-page Current Situation Analysis). ${ }^{[69]}$ The University Libraries at Virginia Tech have a web page devoted to Library Strategic Plan Steps 2000-2001, which lists their Steering Committee and Coordinators and then describes the process, with links to working papers, workshop outputs, and draft plans. ${ }^{[70]}$ The website for the Syracuse plan provides links to progress reports, invites questions about the plan, and allows library staff to express their interest, suggest an initiative, or submit a report. The introductory part of the plan provides an explanation of the process and a glossary of planning terminology; definitions of terms (such as "mission statement" and "planning themes") are also repeated at the relevant points in the text. ${ }^{[66]}$

In summary, contemporary planning statements generally have three main components:

- An introductory section, which sets the context of the document, covering both the external factors and institutional issues.

- The overall strategy, which states the ambitions of the service, expressed in its vision, mission, values, and goals.

- The forward plan, which lays out the intentions for the period, elaborated as strategies and actions with responsibilities and timescales.

The latter may form a separate document, and additional information may be included as appendices (e.g., the remit and/or membership of the planning team, the results of customer surveys, risk analyses, and contingency plans). The introduction may be prefaced by a foreword (from the director or dean).

\section{KEY ELEMENTS}

Irrespective of whether their strategy is formally presented in a single strategic plan or as separate statements, academic libraries typically consider the following areas as part of their planning activities: their mission or purpose; their values and beliefs; their view of the future, expressed in a single vision or multiple scenarios; their directions and goals; their plans for actions and the financial resources required.

\section{Library Missions}

Most academic libraries include a formal statement of their fundamental purpose or mission in 
their strategy documents. The terms "mission" and "purpose" are generally used interchangeably, but some institutions distinguish between purpose as a timeless expression of an organization's reason for existence and mission as a more time-specific concept relating the enduring purpose to current directions and goals. Others see mission as a comprehensive construct embracing not only purpose and function but also values and culture, so that it covers behavioral aspects as well as business focus. The length and format of such statements also varies from a few lines to several paragraphs or a full page, and academic library examples reflect this full spectrum.

A common model is to begin with a sentence or paragraph summarizing the overall role and then supplement this with a set of bullet points or sentences, highlighting key functions or activities. New Mexico State University Library provides a short statement of this type. ${ }^{[57]}$ Sheffield uses a longer version, starting with three sentences that relate its mission to that of the university, locate the library within the institutional structure, and state its leadership role, before listing nine principal objectives or functions. ${ }^{[68]}$

Although the purpose of an academic library has not changed fundamentally, the shifts of emphasis from holdings to access, from print to electronic and from mediation to self-service have led to changes in the phrasing of mission statements to reflect more accurately the customer focus and networked environment of contemporary services; thus, the Mission of the University of Washington Libraries refers to "connecting people with knowledge." [71] Some libraries have also used their mission statements to differentiate themselves from their peers, by highlighting distinctive aspects - exemplified by Birkbeck College Library's Mission to "develop and maintain services which especially suit the needs of students who are in employment." [72]

\section{Service Values}

The production of formal statements of the beliefs or principles that underpin organizational or professional philosophies has become more common over the past decade, and this is reflected in the prominence given to values in current academic library plans. Values statements can be seen as a part of the framework that guides discretionary decision making, along with vision and direction statements. Such statements can be particularly useful at times of rapid change as a means of reassuring people that underlying values remain constant when other things are altering radically. Values statements can also be used to support cultural change by asserting new values seen as critical to success in the future (in conjunction with old ones).

Values statements in library plans typically take the form of a set of words or phrases as headlines, which are then elaborated in a longer phrase or sentence. Libraries have traditionally concentrated on values associated with our professional mission, such as the preservation of our cultural heritage, promotion of information literacy, and protection of intellectual freedom, but they have often also incorporated into their statements references to more general humanistic values, such as democracy, diversity, equity, integrity, literacy, and privacy. Contemporary examples still reflect these important concerns but tend to give more prominence to modes of working and styles of delivery thought necessary for success in the changing environment around us, notably collaboration and partnership, flexibility and responsiveness, initiative and innovation.

Formulating a values statement is a challenging task as the final choice of concepts selected for emphasis inevitably raises questions about points considered but not included in the end product. However, most libraries restrict their statements to around half a page, accepting that it 
is hard to make key messages stand out in a lengthier presentation. The statement of the University of Western Australia Library is a typical example, built around the values of responsiveness, innovation, collaboration, and commitment to quality. ${ }^{[73]}$ In contrast to American and Australian practice, few British academic libraries include values statements in their strategy documents.

\section{Strategic Visioning}

Visioning is now a frequent activity in all types of organizations, as an integral part of strategic planning and management, particularly associated with radical organizational change. Visioning exercises and vision statements are seen as an effective way to capture ideas about the future and to communicate the scale of the transformation envisaged to stakeholders. The content and length of vision statements vary, but most commentators agree that visions need to be both aspirational and inspirational, which means that style and tone are critical factors. Visioning has connotations of a "best," "desirable," or "ideal" future, but there has been a noticeable shift recently from "soft" statements to harder, more realistic, and specific descriptions that contain "actionable" concepts or components. The challenge is to manage the inherent tension between ambition and capability by striking the right balance between idealism and realism.

Library vision statements are mostly around one or two pages long, but published examples range from a few paragraphs to several pages. Purdue University Libraries have used visioning to plan shorter-term changes and also for team building at branch or department level. ${ }^{[50]}$ At the other end of the scale, SCONUL has conducted two visioning exercises to produce a shared national view of academic information services in the future, which have provided guidance and stimulus to members developing their institutional strategies and plans, as well as supporting the work of SCONUL in dealing with other bodies. The resulting statements (which also include planning assumptions) have been used as reference documents, lobbying materials, educational aids, and communication tools at local, regional, national, and international levels. ${ }^{[74]}$, ${ }^{[75]}$

Edinburgh University Library exemplifies the trend toward more realistic and specific vision statements that emphasize capability and actionability. Its strategic vision runs to two pages and contains six key messages, each supported by one or two paragraphs explaining the situation envisaged in more detail. This vision also gains immediacy and power by using the present tense to describe the future. ${ }^{[76]}$ Other academic libraries have chosen to present their visions much more succinctly in a short paragraph or even just a single sentence. Short statements run the risk of blandness and require careful drafting (and redrafting) to ensure that they have real meaning and sufficient focus to distinguish the service from its peers. The University of Washington Libraries have succeeded in outlining several dimensions of their service in only three sentences: "The University of Washington Libraries will anticipate and meet the needs of our communities in their search for knowledge. We will do this at any time and any place. We will use our extraordinary staff and our world-class portal to resources and services in creating a model information literate community." [71]

In a slightly longer statement, the Virginia Tech Libraries concentrate on only two key aspects - collaborative partnership and support in any location — preferring instead to emphasize the library's task as supporting the business of the university:

We will be collaborative partners with members of the university community as we collectively work to position the university as a top-tier research institution. Wherever they are located, members of the Virginia Tech community will be supported by the library as they engage in research, as they share in 
quality learning experiences at the undergraduate and graduate levels, and as they work in transferring knowledge and expertise between the university and society. ${ }^{[7]}$

Macquarie University Library similarly promotes the aspiration of success through partnership in a very short "vision": "To be an indispensable partner in the provision of quality education and research at Macquarie University." [67]

Shorter forms of vision statements such as the above are often referred to more accurately as "positioning statements" or statements of "strategic intent," particularly when they are used alongside longer descriptions of an organization's desired future.

\section{Scenario Development}

Scenarios are simplified descriptions of multiple futures - alternative visions - and are particularly useful when there is concern about the uncertainty of critical planning assumptions. Scenario development involves identifying a range of possible outcomes for key environmental influences and then selecting combinations of these alternative states to articulate different but plausible futures. Properly done, it combines environmental scanning with strategic visioning, using both facts and perceptions - hard and soft inputs - to illuminate the dynamics, crossimpacts, and cause-and-effect relationships of external and internal forces potentially affecting an organization. The scale and pace of change over the last decade has led to renewed interest in scenario development and new publications on the subject, which have been cited and used by library managers. ${ }^{[30]}[78],{ }^{[79]}$

Scenarios are often used to convey the impact and implications of technology on organizations, and this has been a common theme in library scenarios. In 1984, ARL designed four scenarios to use in planning library staff needs for the next decade. ${ }^{[80]}$ In 1996 , to stimulate thinking about a future network-based scholarly communication system, Peters similarly formulated four scenarios written from the perspective of higher education institutions and their libraries: "Another marketplace for global enterprise"; "Mass customisation for and by individuals"; "Knowledge guilds reign supreme;" and "Ivory towers in cyberspace." [81]

Another common use is the production of "resource scenarios" to illustrate the implications of budget adjustments (usually cuts) for organizations. For example, Shapiro describes how administrators at Michigan State University were asked to prepare three brief scenarios showing how their unit would look if its base budget were reduced by $5,10,15 \% .{ }^{[82]}$ More positively, Dewey refers to a request for the University of Iowa Libraries to add three scenarios to their plan, showing what they could accomplish with a $15 \%$ increase, $5 \%$ increase, and $5 \%$ decrease in their budget. ${ }^{[3]}$

Scenarios (like visions) can be used at various levels (e.g., the organization as a whole, a particular department, or a specific project) and for a variety of purposes. They have proved popular and effective in library space planning, enabling more dramatic presentation of the potential impact of a new building on the local learning environment than a conventional proposal. At Reading University Library, alternative scenarios were successfully used in 1997 to communicate the different service implications of building an extension and remodeling existing space. ${ }^{[54]}$ Significantly, the second scenario was not intended to be a "doomsday" vision: it represented a genuine attempt to remodel existing accommodation to meet future needs, but its logic showed the spiraling knock-on effects of space constraints. ${ }^{[83]}$ In 1998, a more structured approach to scenario development was used at the University's Bulmershe Library, in a highly participative exercise involving a wide range of stakeholders. ${ }^{[5]}$ 
At the University of Arizona Library, the Branches Libraries Space Planning Team developed four divergent scenarios - "Book truckin," "Tomorrowland," "Full stop," and "Future on the cheap" - which were summarized as bullet points on a matrix diagram and then described in more detail with current situational abstracts for each one. ${ }^{[84]}$ Staff used a 12-step methodology adapted from established models, covering the whole planning process from identifying the critical decision issue to producing a facilities master plan. ${ }^{[85]}$

Other organizations have developed scenarios for strategic plans or reports purely as illustrative material showing how the same future might look from different perspectives (rather than describing different futures based on varying interpretations of the environment). For example, in 1993 the Follett report offered three "sketches" to illustrate some of the possibilities opened up by the technology of the "virtual library," written from the perspectives of an undergraduate, an academic, and a "virtual librarian." ${ }^{[86]}$ Similarly, Rutgers included five "Scenarios of the future" in their 1999 plan explaining how a professor, an undergraduate, a graduate student, and researchers might find and locate information resources if the proposed Digital Library Initiative became a reality. ${ }^{[65]}$ Examples of this type are more accurately described as "sketches" or "scenes" (rather than "scenarios") in the context of strategic planning.

\section{Goal Statements}

Strategic goals (also known as strategic objectives) are direction statements that indicate the movement or improvement needed to achieve the desired future state (as expressed in the vision). Effective goals are expressed in action-oriented terms that are capable of conversion into specific targets enabling managers to plan tasks and measure performance. Libraries usually group their goals/objectives and targets under broad headings, variously described as "strategic directions," "strategic issues," "strategic priorities," or "strategic thrusts"; "key action areas," "key performance areas," or "key result areas"; "planning imperatives" or "planning themes." For example, Purdue's Plan 2004: A Framework for Action groups its goals under four strategic directions: The Learning Library, Scholarly Communication, User-Centered Services, and Infrastructure. ${ }^{[87]}$

Alternatively, people sometimes just use the term "goal" to denote broad areas that provide a framework for organizing initiatives and actions in groups that have some coherence but not necessarily reflecting day-to-day organizational boundaries. The goal translation process, whereby each top-level "goal," "objective," or "strategy" is converted from a general statement of what you want to achieve to a more specific description of how it will be done, is the key to successful strategy implementation. Moreover, this "what/how" translation process needs to take place at successive levels in the organization, so that institutional goals are converted into library goals and high-level librarywide goals are translated into lower-level goals for library sites or teams.

The University of Sydney Library offers two views of the relationship between University Goals and Library Strategies by ordering things differently in its 5-year Strategic Plan and annual Key Results document. In the former, Library Strategies are grouped as a bullet-point listing under each major University Goal; in the latter, the Strategies (together with details of Actions, Resources, Responsibility, Target Dates, and Performance Indicators) are grouped under 10 Key Result statements, with one or more Associated University Goals listed under each Key Result area. In this way, the library not only shows how it proposes to support each university goal but also explains how the actions taken in a particular year relate to those goals. ${ }^{[88]}$ 
Goals specify the key directions for an organization or service over the planning period, but they cannot be finally confirmed until strategies have been properly developed to the point where the resource implications and organizational dependencies of the actions required can be assessed. Strategy development needs both analytical and creative inputs; many libraries have found it useful to follow a systematic process. For example, the six-step STRIDE model takes planners through a series of questions:

- Situation: What is the current position of the service, product(s), or facilities?

- Targets: What is the overall goal and what are the intermediate objective(s) or milestone(s)?

- Restraints: Are there constraints on progress, such as policies or resources?

- Insights: What information and ideas are needed for a workable strategy?

- Delivery: What exactly needs to be done, by whom, and when?

- Evaluation: How will success be judged and performance measured? ${ }^{[26]}$

\section{Action Planning}

It is debatable how far strategic plans should be developed into action plans, and there is significant variation in practice, with some organizations expressing their strategies in rather general terms, whereas others include quite specific objectives (with numbers attached). There are trends in both directions, with many managers favoring broad-brush statements to give them some flexibility if circumstances change suddenly, but also more organizations requiring identifiable outcomes and making managers formally accountable for the results specified in their plans.

The plan of the University of Washington Libraries is an example of the former type: each Key Action Area is defined by four or five sentences indicating some of the underlying issues, but any statements of intent are at a very general level. ${ }^{[71]}$ Plans of this type, where there are few measurable outcomes specified, could more accurately be described as policy statements in this context. Others state explicitly in the introductory sections of their strategic plans that action planning is separately documented; thus, Sheffield states that "the Library compiles annual Operational Objectives on a rolling three-year basis to enable the plan to be implemented effectively." [68]

There is considerable variation in the detail provided in strategic action plans, ranging from simple lists showing completion dates and persons responsible against the required tasks or desired results to elaborate formulations of initiatives and actions incorporating priority rankings and status reports as well as showing the people involved and the planned timetable. The plan of Birkbeck College Library is at one end of the spectrum, with sets of one-line actions, responsible people, and target dates grouped under eight headings. ${ }^{[72]}$ At the other extreme, for each of its 17 goals, Syracuse University Library provides information on their priority and feasibility (ranked as high/medium/low), the rationale, success indicators, and specific initiatives, and then details the project manager, action team leader, start date, and timescale (short/mid/long-range) for each initiative. Further details are recorded in Action Plan Progress Reports, including action team members, actions to date, modifications to the plan and/or team, obstacles or barriers to progress, and timetable for completion. ${ }^{[66]}$

It is clear that many academic libraries have learned from experience that if they do not develop tightly specified action plans to support their strategies, the desired service developments will just not happen, because of the continuing pressure of day-to-day service 
delivery. Managers also need to think about the extent to which their plans depend on actions and resources from other parts of the organization and take that into account in their planning. Irrespective of whether action plans are included in the strategy document, action planning needs to be seen as part of the planning process.

\section{Financial Commentary}

There is evidently much pressure on academic libraries to identify outcomes and justify expenditure, so it is quite surprising that resourcing and funding issues do not feature more prominently in their strategic plans. Although managers may regard budget reports and projections as confidential or sensitive information, some mention at least of the financial implications or feasibility of their strategies might be expected. Some libraries have at least flagged resourcing as an issue, albeit in fairly general terms. For example, Sheffield draws attention to "the declining purchasing power of its present budget" in the introduction to its plan and also has a specific section on resources reinforcing this point after reference to other funding issues. ${ }^{[68]}$

Others make explicit statements about the funding required to implement their strategies comprehensively. In the Memphis plan, the objectives listed under each major goal are subdivided into those "that can be met with existing resources" and those "that require new/additional resources beyond what the unit is able to generate through restructuring and internal reallocation." ${ }^{[58]}$ The Rutgers plan has a substantial appendix entitled "Budgetary Overview," which sets the goal of parity with the top quartile of AAU universities (in line with institutional aims) and outlines several funding strategies. ${ }^{[65]}$ Edinburgh gives even more prominence to expenditure requirements and income streams, placing "Funding" and "Cost Recovery and Income Generation" first and second of its eight strategic goals, setting targets under both headings and similarly proposing benchmarking against comparators. ${ }^{[76]}$

\section{CONCLUSION}

Strategic planning in academic libraries has evolved over the past three decades from a management concept to established practice. Planning frameworks and strategy processes in higher education have grown in line with administrative changes and external demands. Convergence of library and computing services is taking place at several levels (operational, tactical/developmental, and strategic), and this is reflected in the changing scope of library and information service plans and the development of comprehensive information strategies.

The proliferation of strategies is shifting the focus of attention from the production and implementation of plans to the linking and integration of a "strategy web." Academic libraries have generally seen their strategic plans as both supporting and influencing the higher-level strategies of the institution, but libraries that seize the opportunities offered by creative partnerships to develop joined-up (or joint) plans with related services may see this balance alter and their influence increase. Strategic planning has served us well in the past, and if we continue to adapt and refine our systems and processes, it will help us to create a better future.

\section{REFERENCES}

1. Johnson, G.; Scholes, K. Corporate Strategy, 5th Ed.; Prentice Hall: London, 1999. 
2. Drucker, P.F. Management Butterworth-Heinemann: Oxford, UK 1974, (1988).

3. Dewey, B.I. The University of Iowa Libraries' Strategic Plan. In Strategic Planning in Higher Education: Implementing New Roles for the Academic Library; Williams, J.F., II, Ed.; Haworth Press: New York, 1991, 99-112.

4. Mulhare, E.M. The Library Long-Range Planning Process at Wayne State. In Strategic Planning in Higher Education: Implementing New Roles for the Academic Library; Williams, J.F., II, Ed.; Haworth Press: New York, 1991, 113-129.

5. Cain, L.J.; Louden, W. F. University Libraries and Academic Strategic Planning at the University of Cincinnati. In Strategic Planning in Higher Education: Implementing New Roles for the Academic Library; Williams, J.F., II, Ed.; Haworth Press: New York, 1991, 167-179.

6. Association of Research Libraries, Office of Management Services, Systems and Procedures Exchange Center Strategic Planning in ARL Libraries; SPEC Kit 108; ARL: Washington, DC, 1984.

7. Association of Research Libraries, Office of Management Services, Systems and Procedures Exchange Center Strategic Plans in ARL Libraries; SPEC Kit 158; ARL: Washington, DC, 1989.

8. Association of Research Libraries, Office of Management Services, Systems and Procedures Exchange Center Strategic Planning in ARL Libraries; SPEC Kit 210; ARL: Washington, DC, 1995.

9. Higher Education Staff Development Agency Making management work: A course for practising managers. http://www.hesda.org.uk/events/making.htm (accessed October 2001).

10. Joint Funding Councils' Ad Hoc Group on Performance Indicators for Libraries The Effective Academic Library: A Framework for Evaluating the Performance of UK Academic Libraries: A Consultative Report to the HEFCE, SHEFC, HEFCW, and DENI; The Councils: Bristol, UK, 1995, Chairman: Kevin Ellard.

11. Chandler, A.D. Strategy and Structure: Chapters in the History of the Industrial Enterprise; MIT Press: Cambridge, MA, 1962.

12. Bryson, J.M. Strategic Planning for Public and Nonprofit Organizations: A Guide to Strengthening and Sustaining Organizational Achievement; Jossey-Bass: San Francisco, CA, 1988.

13. Steiner, G.A. Strategic Planning: What Every Manager Must Know; Free Press: New York, 1997.

14. Kotler, P.; Murray, P. E. Strategic planning for higher education. J. High. Educ. 1981, 52 (5) 470-489.

15. Cope, R.G. Strategic Policy Planning: A Guide for College and University Administrators; Ireland Educational Corporation: Littleton, CO, 1978.

16. Keller, G. Academic Strategy: The Management Revolution in American Higher Education; Johns Hopkins University Press: Baltimore, MA, 1983.

17. Meade, P.H. Challenges Facing Universities: Quality, Leadership and the Management of Change; University of Otago: Dunedin, New Zealand, 1997.

18. Watson, D. Managing Strategy; Open University Press: Buckingham, UK, 2000.

19. Berge, Z.L.; Schrum, L. Linking strategic planning with program implementation for distance education. Cause/Eff. 1998, 21 (3) 31-38 . http://www.educause.edu/ir/library/html/cem9836.html (accessed October 2001). 
20. Lerner, A.L. A strategic planning primer for higher education. 1999

http://www.des.calstate.edu/strategic.html (accessed October 2001).

21. Higher Education Funding Council for England Strategic Planning in Higher Education: A Guide for Heads of Institutions, Senior Managers, and Members of Governing Bodies; The Council: Bristol, UK, 2000, http:/www.hefce.ac.uk/Pubs/HEFCE/2000/00_24.htm (accessed October 2001).

22. Riggs, D.E. Strategic Planning for Library Managers; Oryx Press: Phoenix, AZ, 1984.

23. McKee, B. Planning Library Service; Clive Bingley: London, 1989.

24. Jacob, M.E.L. Strategic Planning: A How-To-Do-It Manual for Librarians; Neal-Schuman: New York, 1990.

25. Corrall, S. Strategic Planning for Library and Information Services; Aslib Know How Guide; Aslib: London, 1994.

26. Corrall, S. Strategic Management of Information Services: A Planning Handbook; Aslib/IMI: London, 2000.

27. Giesecke, J., Ed.; Scenario Planning for Libraries; American Library Association: Chicago, IL, 1998.

28. Weingand, D.E. Future-Driven Library Marketing; American Library Association: Chicago, IL, 1998.

29. Gorman, M. Our Enduring Values: Librarianship in the 21st Century; American Library Association: Chicago, IL, 2000.

30. McClure, C. The planning process: Strategies for action. Coll. Res. Libr. 1978, 39 (6) 456466.

31. Davis, P. Libraries at the turning point: Issues in proactive planning. J. Libr. Adm. 1980, 1, 11-24.

32. Biddle, S.F. Planning in the University Library; Greenwood Press: Westport, CT, 1992.

33. Hayes, R.M. Strategic Management for Academic Libraries: A Handbook; Greenwood Press: Westport, CT, 1993.

34. Ensor, P. Strategic planning in an academic library. Libr. Admin. Manage. 1988, 2 (3) $145-$ 150.

35. Baker, S.M. Strategic planning for libraries in the electronic age. IATUL Q. 1989, 3 (4) 200-206.

36. Brindley, L.J. Library development plans - A case study: Aston university library and information services. Br. J. Acad. Librariansh. 1990, 5 (3) 155-158.

37. Gratch, B.; Wood, E. Strategic planning: Implementation and first-year appraisal. J. Acad. Librariansh. 1991, 17 (1) 10-15.

38. Butler, M.; Davis, H. Strategic planning as a catalyst for change in the 1990s. Coll. Res. Libr. 1992, 53 (5) 393-403.

39. Lee, S. Organizational change in the Harvard College Library: A continued struggle for redefinition and renewal. J. Acad. Librariansh. 1993, 19 (4) 225-230.

40. Blunden-Ellis, J. The Consortium of Academic Libraries in Manchester (CALIM): Strategic and Development Planning for a New Consortium. In Resource Sharing: New Technologies as a Must for Universal Availability of Information; Helal, A. H.; Weiss, J. W., Eds.; Universitatsbibliothek Essen: Essen, Germany, 1994, 99-114.

41. Shoaf, E.C. Fifteen months in the planning trenches: Strategically positioning the research library for the new century. Libr. Admin. Manage. 2001, 15 (1) 4-13. 
42. Lynch, B.P., Ed.; The Academic Library in Transition: Planning for the 1990s; Neal Schuman Publishers: New York, 1989.

43. Williams, J.F., II, Ed.; Strategic Planning in Higher Education: Implementing New Roles for the Academic Library; Haworth Press: New York, 1991.

44. Watson, E.I. Transforming the Library: Strategic Planning at Bradley University - The Library Perspective. In Strategic Planning in Higher Education: Implementing New Roles for the Academic Library; Williams, J.F., II, Ed.; Haworth Press: New York, 1991, 137-145.

45. Wilson, P. Mission and information: What business are we in? J. Acad. Librariansh. 1988, 14 (2) 82-86.

46. Brophy, P. The mission of the academic library. Br. J. Acad. Librariansh. 1991, 6 (3) 135147.

47. Forsman, R. Incorporating organizational values into the strategic planning process J. Acad. Librariansh. 1990, 16 (3) 150-153.

48. Birdsall, D.G.; Hensley, O.D. A new strategic planning model for academic libraries. Coll. Res. Libr. 1994, 55 (2) 149-159.

49. Michalak, S. Planning academic library facilities: The library will have walls. J. Libr. Adm. 1994, 20 (2) 93-114.

50. Hewison, N.S. Achieving change in libraries: Vision at the department, branch and team levels. Libr. Adm. Manage. 1995, 9 (3) 153-158.

51. Tuck, J. Operational planning and performance measurement in the John Rylands university library of Manchester. New Rev. Acad. Librariansh. 1995, 1 , 15-31.

52. Bevan, N.; Dolphin, P. Preparing an IT strategy. SCONUL Newsl. 1997, (12) 16-21 .

53. Birdsall, D.G. Strategic Planning in Academic Libraries: A Political Perspective. In Restructuring Academic Libraries: Organizational Development in the Wake of Technological Change; Schwartz, C.A., Ed.; Association of College and Research Libraries: Chicago, IL, 1997, 253-261.

54. Corrall, S. Scenario planning: A strategic management tool for the future. Manag. Inf. 1998, 5 (9) 34-37.

55. Brewerton, A. First, find some visionaries. Libr. Assoc. Rec. 1999, 101 (6) 354-356.

56. Feinman, V.J. Five steps toward planning today for tomorrow's needs. Comput. Libr. 1999, 19 (1) 18-21. http://www.infotoday.com/cilmag/jan99/story1.htm (accessed October 2001).

57. New Mexico State University Library Strategic plan 1997-2002. http://lib.nmsu.edu/aboutlib/straplan.html (accessed October 2001).

58. The University of Memphis Libraries Strategic plan 1998-2003. http://www.lib.memphis.edu/stratgic.htm (accessed October 2001).

59. The University of Queensland Library Profile and operational plan 2001-2004. http://www.library.uq.edu.au/about/ (accessed October 2001).

60. Curtin University of Technology. Library and Information Service LIS Plan 2000-2005. http://lisweb.curtin.edu.au/organization/documents/stratplan2000.html (accessed October 2001).

61. Kaplan, R.S.; Norton, D.P. The balanced scorecard - Measures that drive performance . Harvard Bus. Rev. 1992, 70 (1) 71-79.

62. University of Arizona Library Strategic Long Range Planning Team charge. http://dizzy.library.arizona.edu.pitt.idm.oclc.org/library/teams/slrp/SLRPCharge.html (accessed October 2001). 
63. Mount Holyoke College. Library, Information and Technology Services Strategic plan. http://www.mtholyoke.edu/lits/about/plan/index.shtml (accessed October 2001).

64. Monash University Library Operational plan, 2000-2004. http://www.lib.monash.edu.au/OPlans/2000/2000-4intro.html (accessed October 2001).

65. Rutgers University Libraries A bridge to the future: The Rutgers Digital Library Initiative. 1999 http://www.libraries.rutgers.edu.pitt.idm.oclc.org/rul/about/long_range_plan.shtml (accessed October 2001).

66. Syracuse University Library Strategic plan. http://libwww.syr.edu.pitt.idm.oclc.org/information/strategicplan/index.html (accessed October 2001).

67. Macquarie University Library Strategic plan 1999. http://www.lib.mq.edu.au/resources/staffpublications/strategic/index.html (accessed October 2001).

68. The University of Sheffield Library New worlds of information: The library strategic plan 2001/2001-2003/2004. Mission statement and objectives. http://www.shef.ac.uk/library/libdocs/indexsp.html (accessed October 2001).

69. University of Arizona Library Strategic Long Range Planning Team home page. http://dizzy.library.arizona.edu.pitt.idm.oclc.org/library/teams/slrp/frameref.html (accessed October 2001).

70. Virginia Polytechnic Institute and State University. Virginia Tech University Libraries: Library strategic plan steps 2000-2001. http://www.lib.vt.edu.pitt.idm.oclc.org/info/stratplan/overview.html (accessed October 2001).

71. University of Washington. University Libraries 2001 Strategic plan. Mission. http://www.lib.washington.edu.pitt.idm.oclc.org/about/StrategicPlan2001.html (accessed October 2001).

72. Birkbeck College Library Mission statement and strategic plan. http://www.bbk.ac.uk/lib/STRATPLN.PDF (accessed October 2001).

73. University of Western Australia Library Strategic plan 1999-2001. http://www.library.uwa.edu.au/publications/plan/strategic_plan_1999.html (accessed October 2001).

74. Standing Conference of National and University Libraries The SCONUL Vision: The Academic Library in the Year 2002; SCONUL Briefing Paper; SCONUL: London, 1998, http://www.sconul.ac.uk/vision.htm (accessed October 2001).

75. Standing Conference of National and University Libraries The SCONUL Vision: Academic Information Services in the Year 2005; SCONUL Briefing Paper; SCONUL: London, 2001, http://www.sconul.ac.uk/vision2005.htm (accessed October 2001).

76. University of Edinburgh Library strategy 1999-2002. http://www.lib.ed.ac.uk/lib/about/policy/strategy.shtml (accessed October 2001).

77. Virginia Polytechnic Institute and State University. University Libraries at Virginia Tech: A research library for a major university: The strategic plan for the Virginia tech libraries. [Draft]. http://www.lib.vt.edu.pitt.idm.oclc.org/info/stratplan/overview.html (accessed October 2001).

78. Schwartz, P. The Art of the Long View; Doubleday: New York, 1991.

79. van der Heijden, K. Scenarios: The Art of Strategic Conversation; John Wiley: Chichester, UK, 1996. 
80. Jurow, S.; Webster, D. Building new futures for research libraries . J. Libr. Adm. 1991, 14 (2) 5-19.

81. Peters, P.E. From serial publications to document delivery to knowledge management: Our fascinating journey, just begun. Ser. Libr. 1996, 28 (1/2) 37-55.

82. Shapiro, B.J. Refocusing, Rebalancing, and Refining $\left(\mathrm{R}^{3}\right)$ : The Libraries' Role in Strategic Long-Range Planning at Michigan State University. In Strategic Planning in Higher Education: Implementing New Roles for the Academic Library; Williams, J.F., II, Ed.; Haworth Press: New York, 1991, 79-98.

83. Corrall, S. University library: Visions of the future. Univ. Read. Bull. 1997, (313) 6-7. See also http://www.rdg.ac.uk/libweb/Lib/Report/scenarios.html (accessed October 2001).

84. University of Arizona Library Scenarios main page. http://www.library.arizona.edu.pitt.idm.oclc.org/library/teams/space9798/branches/scenario/ scenario.htm.

85. University of Arizona Library Scenario planning process. [Working draft]. http://www.library.arizona.edu.pitt.idm.oclc.org/library/teams/space9798/branches/overvie w/process 1.htr.

86. Joint Funding Councils' Libraries Review Group Report; The Councils: Bristol, UK, 1993, (Chairman: Professor Sir Brian Follett). http://www.ukoln.ac.uk/services/papers/follett/report/ch7.html (accessed October 2001).

87. Purdue University Libraries Plan 2004: A framework for action. http://www.lib.purdue.edu/plan2004/framework_for_action.html.

88. University of Sydney Library Planning documents, Strategic plan 1999-2004; Key results 2000. http://www.library.usyd.edu.au/staff/plan/. 